\title{
Aposentação de Advogados
}

\author{
Dr. João Arruda
}

\section{INDICAÇÃO}

Indico seja nomeada uma commissão que estude o modo de se instituir uma pensão em favor dos advogados que, pela avançada edade, não mais queiram viver da profissão.

\section{SUSTENTAÇÃO}

De um elevado numero de collegas, ao darem sua opinião acerca da assistencia com que a Ordem conseguiu acudir aos advogados impossibilitados de trabalho por molestia, ouvi ser necessario não esquecer os profissionaes que, embora em gozo de saúde (si é que senectus non est morbus), se encontrem em circumstancias de não mais quererem ou poderem prover á subsistencia pela lucta forense, que não dispensa inteiramente as forças de que são ricos os moços. Nem deixam de fazer-me sentir, embora sem segunda intenção, que eu tenho, na qualidade de professor aposentado, essa "misère honorable que l'État reserve à ses anciens serviteurs", na phrase de Coppée. Justa é a ponderação. Não fosse meu precario estado de saúde, e eu trataria de estudar o modo por que poderia a Ordem chegar a este resultado, que não é mais do que complemento do soccorro já concedido a outras classes de nossa sociedade.

Seja-me, comtudo, permittido dizer algo sobre o assumpto, que meus collegas, membros da commissão a ser constituida, cujos conhecimentos não quero depreciar, poderão tomar como prova do muito que ha a fazer para a solução do problema, e das muitas difficuldades que o 
inçam. Particularmente em França tem essa medida de aposentação dos trabalhadores sido fecunda em sua applicação, e isto naturalmente graças á tendencia do francez, desde o mais liberal até o mais estitico, de economizar, podendo dizer-se que é sua idéa fixa constituir uma renda vitalicia, e constantemente recolher a seu mealheiro qualquer coisa, na crença de que "petit a petit l'oiseau fait son nid." A renda vitalicia é objecto dos arts. 1.968 e segs. do Codigo Civil, e deve ser considerada como sendo contracto de méra iniciativa particular. Não assim o soccorro para aposentação dos que chegam á velhice, ou são feridos pela accidental invalidez: data sua organização da lei de 5 de Abril de 1910, á qual se seguiram mais de 50 outras até 5 de Abril de 1928, ultima de que tenho noticia pelo Repertorio Dalloz. A commissão verificará quanta disputa houve sobre a melhor maneira de constituir o fundo de assistencia, e muito proveitosa poderá ser a experiencia franceza para nós brasileiros, sem embargo da grande differença de genio existente entre francez e brasileiro: aquelle, homem da economia, e este o da dissipação. Insisto em não querer menosprezar a cultura da commissão.

Não é comtudo novo em nossa systematica juridica o instituto da renda vitalicia, como se mostra pelos estudos valiosissimos de Lobão em seu tratado sobre os censos $(\S 20)$ : depois de definir o censo nas varias modalidades, sustenta que podem todas ser comprehendidas na definição "omnis annua praestatio, seu pensio". Mas, e é este o ponto que, sem duvida, mais me impressionou, si é certo que a Constituição Federal prometteu a instituiçãa de previdencia para os trabalhadores (art. $121 \S 1$ letra $h$ ), não é menos verdade que equiparou os intellectuaes aos manuaes ( $\S 2)$. Indifferente me parece se tracte de operario assalariado no sentido restricto da expressão, si de homem que presta seu serviço por outra fórma de pagamento, occorrendo-me á memoria que, segundo Mirabeau, citado por Gide (Vol. II pag. 282), todo homem é ou ladrão, ou mendigo, ou assalariado: "Je ne connais que trois manières d'exister dans la société: il 
faut y être mendiant, voleur ou salarié”. Ainda quando não contribua para o fundo de soccorro o Estado, como deveria concorrer para o caso previsto no art. $121 \S 1$ letra $h$, importando esta falta em ataque ao art. $121 \S 2$, facil seria acudir á velhice desamparada dos luctadores forenses contribuindo o cliente e o proprio advogado com uma parte do indispensavel para a formação da reserva para pensão á senilidade, e quiçá á invalidez.

Referi-me, linhas acima, ao elevado numero de leis francezas sobre a materia, mas devo ajuntar que os jurisconsultos enriqueceram a literatura do paiz com suas valiosas monographias, segundo vejo nos catalogos. Mencionarei os trabalhos de Albert, Courelle, Dalloz, Goineau e Rissert, Le Henaf, Pinot e Comolet, Tirman, Pothenont e Sachet. Muitos outros ainda poderiam ser enumerados. Mesmo quanto ás legislações estrangeiras, ha as obras de Dalloz, Sachet e Bellon. Devo, neste ponto, fazer menção de que a Italia teve, em Maio de 1907, sua primeira lei acerca da aposentação dos trabalhadores em profissões mechanicas (lavoratori manuali): é ella digna de leitura. Tambem muito proveitosos devem ser os trabalhos juridicos sobre o assumpto no culto paiz. Recommendo: Baldi - Dir. Ind.

Parece-me que a competencia sobre tal assumpto é da União, mas a ninguem será licito negar que o Estado de São Paulo poderá, em caso de demora de providencia da Federação sobre tão grave caso, acudir á necessidade com legislação, beneficiando com este grande melhoramento os que mourejam no fôro paulista.

Não tracto de assumpto que se possa capitular propriamente na assistencia social, como é o sobre que, com tanto applauso do fôro, providenciou o nosso illustrado collega Dr. Plinio Barreto, mas de estatuir normas sobre o premio ao trabalho: uma pensão pelo serviço feito. Ainda porém que fosse o caso de assistencia, seria possivel attribuir ao Estado de São Paulo a competencia nos termos do art. 5 n. XIX letra $c$ da Constituição Federal. Sendo porém de regulamentação do trabalho, fica comprehendido no mesmo 
art. 5 n. ${ }^{\circ}$ XIX letra $i$, combinando-se estas disposições com o $\S 3$ do referido artigo.

Fique porém firmado que eu preferiria fosse a lei geral para todo o Brasil, e portanto de origem na Camara dos Deputados representantes da União.

Uma questão prejudicial todavia surge, seja a lei federal, seja estadual: haverá necessidade de acudir aos advogados brasileiros que attingiram uma edade avançada no exercicio da profissão? Fóra de duvida é para mim que os velhos são mais procurados que os moços: o advogado velho não perde a clientela, e, ao contrario, a vê crescer, não obstante a propaganda constante dos jovens, que affirmam serem os homens edosos incapazes de dar, como se diz na gira forense "uma rasteira no adversario". O povo em geral pensa de accôrdo com o provérbio italiano: "Parrucchiere giovine, avvocato vecchio". Por outro lado é de considerar que o trabalho se torna cada vez mais facil para o advogado: faço hoje seguramente em muitissimo menos tempo que na mocidade o serviço forense a mim confiado. Só mesmo em caso de accidente mórbido, ha a incapacidade do velho para acudir ao seu mistér no fôro.

Direi, em solução a este ponto delicadissimo, que não estou a occupar-me com assistencia, e assim repito o já dicto linhas acima, mas sim de um premio ao esforço de um luctador pelo interesse publico: só os espiritos mesquinhos ou os charros homens que não podem avaliar a importancia da hodierna organização social serão capazes de negar o alcance do serviço prestado pelos advogados e mais pessôas que luctam pela justiça nas lides forenses incruentas, sim, mas que defendem a sociedade contra seus inimigos internos. assim como as cruentas a defendem contra os externos.

Portanto, e nesta mesma ordem de idéas, proponho que a commissão tome como sendo unico facto gerador do direito á aposentação do advogado a affirmativa por este feita de que deixa de exercer a advocacia, sem dar motivos de 
tal resolução, e ajuntando não ter vencimentos de aposentado por outro titulo. Mais ainda cumpre, creio eu, para não offender susceptibilidades, seja a aposentação outorgada, indifferentemente a pobres, abastados ou opulentos, prohibida sómente, como ficou dicto, accumulação de aposentadorias. Unico requisito: ter exercido por certo tempo (que será fixado pela lei) a advocacia, e querer deixar o trabalho forense.

Comquanto inteiramente seguro da capacidade dos membros da commissão á qual espero seja confiado o estudo do importante problema de que estou a occupar-me, não pude furtar-me a discutir com diversos collegas acerca da maneira de constituir o fundo de reserva para occorrer ao serviço de aposentação dos advogados velhos. A opinião que prevaleceu é a de formar-se a reserva por meio de contribuição dos proprios advogados e dos clientes ou litigantes, inspirando-nos no art. 121 letra $h$ da Constituição Federal. Deverá o advogado pagar em sellos adhesivos 50 réis por folha de serviço que fizer em autos, sem direito a reembolso; e o cliente, 50 réis por folha de processo com direito a reembolso pelo adversario no caso de ser este condemnado nas custas.

Sem menoscabar os dotes de nossos deputados, creio que impossivel é uma assembléa fazer obra tão perfeita quanto uma commissão de juristas, mórmente $\mathrm{cm}$ assumpto de interesse directo da classe a que pertencem estes profissionaes. Por este motivo direi aos meus collegas que derem parecer sobre esta minha indicação parecer-me utilissimo apresentem um projecto completo, de fórma a habilitar o legislador a (feita uma ou outra pequena modificação ou emenda) approval-o em sua integra.

Eis minha proposta, e creio que completa ella a referente á assistencia aos nossos collegas por qualquer motivo feridos de invalidez. O movimento social não é só em pról dos que foram victimas de uma desgraça, mas tambem dos 
que prestaram serviços á communhão. Não nos esqueçamos de que Novicow affirmou valer um homem pelo que fez em serviço da sociedade em que viveu ou da humanidade: é este o titulo de benemerencia de quem comprehende o dever de solidariedade social.

São Paulo, 20 de Outubro de 1936. 